\title{
HUBUNGAN PENYESUAIAN DIRI DAN OPTIMISME DENGAN POST POWER SINDROM DALAM MENGHADAPI MASA PENSIUN PADA PNS DI KABUPATEN LABUHAN BATU
}

\author{
Reni Kartikaningsih \\ Dosen Tetap Fakultas Ekonomi dan Bisnis, Universitas Labuhanbatu \\ E-Mail : cahyaningrembulan0@gmail.com
}

\begin{abstract}
ABSTRAK
Penelitian ini bertujuan untuk melihat 1). Hubungan antara Penyesuaian Diri dengan Post Power Syndrome Dalam Menghadapi Masa Pensiun 2). Hubungan antara Optimisme dengan Post Power Syndrome Dalam Menghadapi Masa Pensiun 3). Hubungan antara Penyesuaian Diri dan Optimisme dengan Post Power Syndrome Dalam Menghadapi Masa Pensiun.

Data penelitian dilakukan melalui skala Optimisme, skala Penyesuaian Diri dan Skala Post Power Syndrome. Penelitian dilakukan terhadap 71 orang yang menghadapi pensiun dengan tehnik total sampling. Analisis data dilakukan dengan tehnik analisa regresi berganda.

Hasil penelitian adalah sebagai berikut ; 1). Terdapat hubungan yang sangat signifikan antara penyesuaian diri dan optimisme terhadap Post Power Syndrome PNS yang akan memasuki masa pensiun. 2). Ada hubungan negatif yang sangat sinifikan antara penyesuaian diri dengan Post Power Syndrome pada PNS yang akan memasuki masa pensiun 3). Ada hubungan positif yang sangat signifikan antara optimisme dengan Post Power Syndrome terhadap Post Power Syndrome PNS yang akan memasuki masa pensiun .
\end{abstract}

Kata kunci : Post Power Syndrome, Penyesuaian Diri dan Optimisme

\section{A. Pendahuluan}

Pria maupun wanita dengan bekerja selain untuk mencapai aktualisasi diri juga bertujuan memenuhi kebutuhannya. Individu berharap dengan bekerja dapat memperoleh keadaan yang lebih memuaskan daripada sebelumnya atau taraf kehidupan yang lebih baik. As'ad, (2004) juga berpendapat bahwa individu didorong bekerja karena individu berharap bahwa hal ini akan membawa pada keadaan yang lebih memuaskan dari pada keadaan sekarang.

Ketika individu mencapai suatu keberhasilan dalam pekerjaannya, individu akan berusaha mengaktualisasikan secara optimal, keterampilan dan kemampuan yang dimiliki, sehingga memiliki posisi atau jabatan yang baik dalam tempatnya bekerja. Akan tetapi manakala suatu waktu, individu juga harus siap melepas 
jabatan tersebut. Apabila mengalami perubahan yang berkaitan dengan pekerjaan, umumnya diawali ketika masa pensiun.

Pensiun pasti dialami oleh setiap individu yang bekerja baik itu pria maupun wanita. Pensiun menurut kamus besar bahasa Indonesia (2008) adalah tidak bekerja lagi karena masa tugasnya telah selesai. Menurut Schwart (dalam Hurlock, 2009 ) mengatakan bahwa pensiun merupakan akhir dari pola hidup. Pensiun dapat diartikan sebagai keadaan individu yang telah berhenti bekerja yang menjadi kebiasaan atau aktivitas aktivitas yang harus dilakukan sehari hari. Tiap individu yang sudah tidak bekerja lagi disebut sebagai pensiunan.

Memasuki masa pensiun tiap individu memiliki cara yang berbeda beda untuk menghadapi masa tersebut. Cara yang ditempuh bermacam macam seperti menabung dari hasil bekerja dengan tabungannya tersebut berharap dapat menikmati masa pensiun dengan tenang. Mengandalkan uang pensiun yang diterima setiap bulannya, atau mengikuti program pra pensiun yang dilakukan perusahaan di mana dia bekerja dengan mengikuti pelatihan wirausaha. Persiapan itu dilakukan dengan harapan setelah pensiun para pekerjanya dapat tetap berkarya atau memiliki aktivitas yang masih bisa dilakukan. Berbagai persiapan tersebut dilakukan agar dapat menjalani masa pensiun dengan tenang.

Menurut penelitian Dinsi (2006) pihak yang paling takut menghadapi masa pensiun adalah Pegawai Negeri Sipil (PNS). Para Pegawai Negeri Sipil yang telah habis masa purna tugasnya atau pensiun, mengalami mental shock (faktor kejiwaan). Menjelang akhir masa kerjanya, mereka tampak kurang beraktivitas dan sering sakit-sakitan. Mental shock ini terjadi, karena adanya ketakutan tentang apa yang harus dihadapi kelak, ketika masa pensiun tiba. Terasa ada sesuatu yang hilang dari dirinya, karena pekerjaan dan jabatan yang selama ini dipegang, harus ditinggalkan. Kehilangan pekerjaan dan jabatan inilah yang membuat mereka stres, cemas dan depresi

Penelitian Manik (2012) menemukan bahwa kemampuan penyesuaian diri pada situasi yang kurang menyenangkan dalam menghadapi pensiun dan bereaksi terhadap stimulus dari lingkungan sosialnya, akan membawa pengaruh pada 
perilaku yang positif. Berpikir positif adalah berusaha mencapai hal terbaik dari keadaan terburuk. Bagi para individu yang telah memasuki masa pensiun maka dibutuhkan optimisme yang tinggi untuk menjalani masa pensiun tersebut. Rasa optimisme yang tinggi akan membuat individu telah pensiun merasa yakin memiliki kekuatan untuk menghilangkan pemikiran negatif, berusaha gembira meskipun tidak dalam kondisi gembira.

Apabila individu yang memasuki masa pensiun tidak memiliki optimisme maka akan muncul rasa putus asa, terkucilkan ketegangan, tekanan batin, rasa kecewa dan ketakutan yang menggangu fungsi fungsi organik dan psikis, sehingga mengakibatkan macam-macam penyakit. Penyakit yang muncul bisa berupa penyakit fisik dan psikis, salah satunya adalah post power syndrome.

\section{B. Literatur Review}

Arti dari "syndrome" itu adalah kumpulan gejala. "Power" adalah kekuasaan. Jadi, terjemahan dari post power syndrome kira-kira adalah gejalagejala pasca kekuasaan. Gejala ini umumnya terjadi pada orang-orang yang tadinya mempunyai kekuasaan atau menjabat satu jabatan, namun ketika sudah tidak menjabat lagi, seketika itu terlihat gejala-gejala kejiwaan atau emosi yang kurang stabil. Gejala-gejala itu biasanya bersifat negatif, itulah yang diartikan post power syndrome. Secara umum (Daradjat, 1985) dijelaskan syndrome ini bisa dikatakan sebagai masa krisis dan kalau digolongkan krisis ini adalah semacam krisis perkembangan.

Dalam Hurlock (1980), post power syndrome adalah salah satu bentuk kecemasan pada orang usia lanjut, yang mengakibatkan dirinya bersikap lebih sensitif dari biasanya, karena sesuatu hal. Post power syndrome banyak dialami oleh mereka yang baru saja menjalani masa pensiun. Istilah tersebut muncul untuk mereka yang mengalami gangguan psikologis saat memasuki waktu pensiun. Stres, depresi, unhappy, merasa kehilangan harga diri dan kehormatan adalah beberapa hal yang dialami oleh mereka yang terkena post power syndrome 
Menurut Hurlock (1996) Ada beberapa faktor yang menyebabkan terjadinya post power syndrome yaitu :

a. Pensiun dini dan PHK. Bila orang yang mendapatkan pensiun dini tidak bisa menerima keadaan bahwa tenaganya sudah tidak dipakai lagi, walaupun menurutnya dirinya masih bisa memberi kontribusi yang signifikan kepada perusahaan, post power syndrome akan dengan mudah menyerang. Apalagi bila ternyata usianya sudah termasuk usia kurang produktif dan ditolak ketika melamar di perusahaan lain, post power syndrome yang menyerangnya akan semakin parah.

b. Kejadian traumatik juga menjadi salah satu penyebab terjadinya post power syndrome. Misalnya kecelakaan yang dialami oleh seorang pelari, yang menyebabkan kakinya harus diamputasi. Bila dia tidak mampu menerima keadaan yang dialaminya, dia akan mengalami post power syndrome. Dan jika terus berlarut-larut, tidak mustahil gangguan jiwa yang lebih berat akan dideritanya.

c. Penyesuaian diri ; Hurlock (1996) menyatakan bahwa penyesuaian diri merupakan salah satu faktor yang mempengaruhi munculnya kecemasan dalam menghadapi masa pensiun, karena pada saat memasuki masa pensiun individu akan mengalami suatu perubahan pola hidup. Individu harus menyesuaikan diri dengan masa pensiun dan berkurangnya penghasilan keluarga, menyesuaikan diri dengan menurunnya kekuatan fisik dan kesehatan, menyesuaikan diri dengan kematian pasangan hidup, membentuk hubungan dengan orang-orang yang seusianya, dan menyesuaikan diri dengan peran sosial secara luwes. Perubahan-perubahan tersebut sangat menuntut adanya penyesuaian diri. Kecemasan menghadapi masa pensiun akan lebih terasa pada individu yang memiliki penyesuaian diri yang buruk.

d. Dukungan keluarga; Dukungan dan pengertian dari orang-orang tercinta sangat membantu penderita. Bila penderita melihat bahwa orang-orang yang dicintainya memahami dan mengerti tentang keadaan dirinya, atau ketidak mampuannya mencari nafkah, ia akan lebih bisa menerima keadaannya dan 
lebih mampu berpikir secara dingin. Hal itu akan mengembalikan kreativitas dan produktifitasnya, meskipun tidak sehebat dulu. Akan berbeda hasilnya jika keluarga malah mengejek dan selalu menyindirnya, menggerutu, bahkan mengolok-oloknya.

e. Optimisme ; Individu yang optimis cenderung memiliki kesehatan yang baik karena optimisme menghasilkan kesehatan yang baik dan bahkan memperpanjang usia seseorang, sehingga tidak takut pada situasi yang baru dan kurang menyenangkan, seperti pensiun. Keadaan ini membuat individu mampu mengatasi terjadinya post power sindrom.

f. Kematangan Emosi ; Kematangan emosi seseorang sangat berpengaruh pada terlewatinya fase post power syndrome ini. Seseorang yang bisa menerima kenyataan dan keberadaannya dengan baik akan lebih mampu melewati fase ini dibanding dengan seseorang yang memiliki konflik emosi. Schneiders (1964) mengungkapkan penyesuaian diri adalah kemampuan atau kapasitas individu untuk bereaksi secara efektif terhadap kenyataan, situasi dan hubungan sosial untuk mencapai kehidupan social yang memuaskan. Penyesuaian diri mempunyai ciri-ciri tertentu yaitu adanya motif yang melatarbelakangi munculnya perilaku,ada rintangan dari lingkungan yang menghambat, respon yang muncul pada masing-masing individu bervariasi dan berakhir dengan penemuan suatu pemecahan.

Optimisme secara sederhana menurut Kamus Besar Bahasa Indonesia (2003) adalah ; "paham (keyakinan) atas segala sesuatu dari segi baik dan menyenangkan; sikap selalu mempunyai harapan baik dan menyenangkan." Menurut Seligman (2006), optimisme adalah keyakinan individu bahwa peristiwa buruk/kegagalan hanya bersifat sementara, tidak mempengaruhi aktivitas dan tidak mutlak disebabkan diri sendiri tetapi bisa situasi, nasib atau individu lain. Individu yang optimis menganggap kegagalan disebabkan oleh sesuatu hal yang dapat diubah, sehingga dapat berhasil pada masa-masa mendatang. Individu yang pesimis menerima kegagalan sebagai kesalahanya sendiri, menganggapnya berasal dari pembawaan yang telah mendarah daging yang tidak dapat diubah.

\section{Metodelogi Penelitian}


Tipe penelitian ini adalah kuantitatif, yaitu penelitian yang sumber datanya adalah berupa angka-angka yang akan dianalisis dengan metoda statistik untuk membuktikan hipotesis yang diajukan. Populasi penelitian dalam penelitian ini adalah pensiunan PNS di Kabupaten Labuhan Batu Selatan yang berjumlah 71 orang. Seluruh Populasi akan di jadikan Sampel (Total Sampling)

Metode pengumpulan data dalam penelitian ini adalah menggunakan metode skala psikologi sedangkan Metode analisis data yang digunakan untuk menguji hipotesis penelitian yaitu Hubungan antara Penyesuaian Diri dan Optimisme dengan Post Power Sindrom digunakan Analisis Regresi Berganda.

\section{Hasil Penelitian}

Melihat hasil uji coba dari skala penyesuaian diri, diketahui bahwa dari 48 butir pernyataan terdapat 5 aitem yang gugur, dan aitem yang valid berjumlah 43 , untuk skala optimisme, diketahui bahwa dari 57 butir pernyataan terdapat 5 butir pernyataan yang gugur. Kemudian untuk skala Post Power Syndrome, diketahui bahwa dari 63 butir pernyataan, terdapat 9 pernyataan yang gugur. Sejalan dengan sistem yang digunakan dalam penelitian ini, maka data dari butir-butir valid dari ke tiga variabel tersebut, diambil untuk digunakan sebagai data penelitian. Maksudnya adalah nilai dari butir-butir valid masing-masing skala dijumlahkan kembali, kemudian setelah diketahui jumlah nilai dari skala penyesuaian diri, skala optimisme dan skala Post Power Syndrome dari masing-masing personil. Selanjutnya ditetapkan bahwa penyesuaian diri $\left(\mathrm{X}_{1}\right)$ dan optimisme $\left(\mathrm{X}_{2}\right)$ sebagai variabel bebas dan sebagai variabel terikat (Y) adalah Post Power Syndrome.

\section{E. Kesimpulan}

(1)Terdapat hubungan yang sangat signifikan antara penyesuaian diri dan optimisme terhadap Post Power Syndrome PNS yang akan memasuki masa pension (2)Ada hubungan negatif yang sangat sinifikan antara penyesuaian diri dengan Post Power Syndrome pada PNS yang akan memasuki masa pensiun di Kab. Labuhan Batu (3)Ada hubungan positif yang sangat 
signifikan antara optimisme dengan Post Power Syndrome, dengan sumbangan efektif yang didapatkan sebesar 58,4\%. (4)Hasil lain diperoleh dari penelitian ini, yakni diketahui bahwa subjek penelitian ini yaitu PNS yang akan memasuki masa pensiun Kab. Labuhan Batu Selatan, memiliki penyesuaian diri yang tergolong cukup rendah dan memiliki optimisme yang tergolong cukup rendah dan Post Power Syndrome yang cukup tinggi.

\section{Daftar Pustaka}

Arikunto, Suharsimi. 2006. Prosedur Penelitian Suatu Pendekatan Praktik. Jakarta : Rineka Cipta.

As'ad, Moh. 2004. Seri Ilmu Sumber Daya Manusia Psikologi Industri.

Yogyakarta : Liberty.

Azwar, Saifuddin. 2003. Tes Prestasi. Yogyakarta : Pustaka Pelajar. 2001. Reliabilitas dan Validitas. Yogyakarta: Pustaka Pelajar 2004. Penyusunan Skala Psikologi. Yogyakarta : Pustaka

\section{Pelajar}

Sudjana. 2000 . Metode Peneltian.Jakarta : Rineka Cipta.

Chaplin, C.P. 1999. Kamus lengkap psikologi. Jakarta: PT. Raja Grafindo Persada

Fokus Media, Tim Penulis. 2012 . Pokok Pokok Kepegawaian Pegawai Negeri Sipil. Jakarta: Fokus Media

Utama Dinsi, V,. Setiati, E., \& Yuliasari, E. 2006. Ketika Pensiun Tiba. Jakarta : Wijayata Media Utama.

Hartanti, Netty. 2002. Post Power Syndrome sebagai Gangguan Mental pada Masa Pensiun. Tazkia Jurnal Psikologi Berbasis Keilmuan

Handayani, A. 2007. Pensiun Bukan Akhir Segalanya. Jakarta. Bulan Bintang

Handayani,Y.2008. Post Power Syndrome pada Pegawai Negeri Sipil yang Mengalami Masa Pensiun. Jakarta: gunadarma

Ghufron, M Nur \& Risnawati, R. 2011. Teori Teori Psikologi. Yogyakarta: ARRuzz Media

Gustian, Erna. 2009. Pensiunan Lebih Sehat Fisik dan Mental dengan Terus Bekerja. www.detikhealth.com (diakses 21 Desember 2014)

Hurlock, Elizabeth B. 2009. Psikologi Perkembangan Suatu Pendekatan Sepanjang Rentan Kehidupan. Jakarta: Erlangga

Kartono, Kartini. 1989. Hygiene Mental. Bandung: Mandar Maju. 
Hadi, S. 1996. Metodologi Research 2. Edisi Revisi.Yogyakarta: Andi Offset Alex, Sobur. 2003. Psikologi Perkembangan. Bandung: Pustaka Setia Desmita. 2009. Psikologi Perkembangan. Bandung: Remaja Rosda Karya Maramis, Willy dan Albert.2009. Catatan Ilmu Kedokteran Jiwa Edisi 2. Surabaya: Airlangga University Press.

Kartono, Kartini. 2002. Patologi Sosial 3. Jakarta: PT Raja Grafindo Persada.

Nofita, Effy.2011. Post Power Syndrome in Retired Manager Women. Surabaya: Airlangga

Pandya, Gunjan.2012. UU Tenaga Kerja Tidak Menentukan Batas Usia Pensiun. Yogyakarta: Pyramid Publisher

Pitaloka, Ardiningtyas.2008. Sikap Hidup di Hari Senja. Bandung: Aneka Ilmu

Purwanti, Puji. 2009. Post Power Syndrome Pada Purnawirawan Kepolisian Negara Republik Indonesia Ditinjau Dari Harga Diri. Skripsi. Universitas Katolik Soegijapranata.

Safaria, Triantoro. 2007. Optimismtic Quotient. Yogyakarta: Pyramid Publisher

Salkind, Neil J. 2009. Teori Teori Perkembangan Manusia. Bandung: Penerbit Nusa Media

Santoso, Agus \& Lestari, Novi B. 2008. Peran Serta Keluarga pada Lansia yang Mengalami Post Power Syndrome. Jakarta: Media Ners.

Santrock, John W. 2002. Life Span Development: Perkembangan Masa Hidup, Edisi 5, jilid II. Jakarta: Erlangga

Seligman, Martin E.P. 2006. Learned Optimism: How to Change Your Mind and Your Life. New York: Vintage Books Semium,

Yustinus. 2010. Kesehatan Mental 3. Yogyakarta: Kanisius.

Seniaty, L, Yulianto, A.,\& Setiadi, B.N. 2009. Psikologi Eksperimen. Jakarta: PT

Indeks. Tim Penyusun. 2003. Kamus Besar Bahasa Indonesia. Jakarta: Balai Pustaka

Travis, Carol \& Wade, Carole. 2007. Psikologi Jilid 2. Jakarta: Erlangga.

Wahyuni.2003. Penyesuaian Diri Lansia, Perkembangan Emosi.Jakarta: Media nurse

Hutapea, R. 2005. Sehat dan Ceria di Usia Senja Melangkah dengan Anggun.

Jakarta: Rieneka Cipta

Supriyono, Iman. 2014. Menghadapi Masa Pensiun. Surabaya: Pustaka Progressif

Media, Fokus. 2012. Pokok-Pokok Kepegawaian Pegawai Negeri Sipil PNS.

Jakarta: Fokus Media

Alwisol. 2004. Psikologi Kepribadian. Malang: UMM Press

Yusuf, Tarmizi. 2009. Mencegah Post Power Syndrome Pasca Pensiun. Jakarta:

Salemba Empat

Sutarto, J.Tito \& C,Ismul, Cokro. 2008. Pensiun Bukan Akhir Segalanya. Jakarta:

Gramedia

Hardjana, A,M. 2003. Komunikasi Intrapersonal dan Interpersonal. Yogyakarta: Kanisius

Yusuf, Syamsu. 2009. Terapi Psikospiritual untuk Hidup Sehat Berkwalitas. Bandung: Maestro

Sarwono, S. 1991. Psikologi Sosial. Jakarta: Balai Pustaka 